\title{
Optimization of Solid Oxide Cells and Stacks for Reversible Operation
}

\author{
Ploner, Alexandra; Hauch, Anne; Pylypko, Sergii; Di lorio, Stéphane; Cubizolles, Géraud; Mougin, Julie
}

Published in:

ECS Transactions

Link to article, DOI:

$10.1149 / 09101.2517$ ecst

Publication date:

2019

Document Version

Peer reviewed version

Link back to DTU Orbit

Citation (APA):

Ploner, A., Hauch, A., Pylypko, S., Di lorio, S., Cubizolles, G., \& Mougin, J. (2019). Optimization of Solid Oxide Cells and Stacks for Reversible Operation. ECS Transactions, 91(1), 2517-2526.

https://doi.org/10.1149/09101.2517ecst

\section{General rights}

Copyright and moral rights for the publications made accessible in the public portal are retained by the authors and/or other copyright owners and it is a condition of accessing publications that users recognise and abide by the legal requirements associated with these rights.

- Users may download and print one copy of any publication from the public portal for the purpose of private study or research.

- You may not further distribute the material or use it for any profit-making activity or commercial gain

- You may freely distribute the URL identifying the publication in the public portal 


\title{
Optimization of Solid Oxide Cells and Stacks for Reversible Operation
}

\author{
Alexandra Ploner ${ }^{1}$, Anne Hauch ${ }^{1}$, Sergii Pylypko², Stéphane Di Iorio ${ }^{3}$, Géraud \\ Cubizolles $^{3}$, Julie Mougin ${ }^{3}$ \\ ${ }^{1}$ Technical University of Denmark (DTU), Denmark, DK-4000 Roskilde \\ ${ }^{2}$ Elcogen AS, Estonia, EE-11415 Tallinn \\ ${ }^{3}$ Univ. Grenoble Alpes - CEA/LITEN, 17 rue des Martyrs, F-38054 Grenoble Cedex 9, \\ France
}

\begin{abstract}
Solid oxide cells are among the best candidates for viable energy conversion and storage solutions. Their capability to operate reversibly as electrolyser ('SOEC mode') or as fuel cell ('SOFC mode') provides an opportunity to balance out electricity needs. Yet, reversible operation requires an optimized cell and stack design to withstand alternating conditions.

In this study, more than ten different cells have been produced and their initial performance evaluated. For selected cells, durability tests were conducted and showed that primarily the oxygen electrode contributes to performance losses in SOFC mode, whereas the fuel electrode is mainly affected under SOEC mode conditions.

The stack design was optimized in order to withstand the envisaged operating conditions. An optimization of internal pressure drop (reduced by a factor of 2) and sealing resistances towards higher pressure has been achieved while maintaining the electrochemical performance.
\end{abstract}

\section{Introduction}

With Europe's growing share of electrical energy production via wind turbines and solar panels, viable energy storage solutions are an essential asset to provide energy on demand (1). Although there are various emerging technologies (e.g. rechargeable or flow batteries, fuel cells, molten salt etc.), the final choice and implementation clearly depends on specific service requirements and costs. With focus on high energy densities and efficiencies, potentially long discharge times (hours to weeks) and the capability of direct conversion of carbon-based fuels or $\mathrm{H}_{2}$ to electricity (SOFC mode) and re-production of hydrogen or syn-gas (SOEC mode) Solid Oxide Cells become highly attractive in terms of energy storage (2). The same electrochemical cell is capable to operate in either SOFC or SOEC mode. Yet, aside from the known degradation aspects in each mode $(3,4)$, reversible usage additionally involves inversion of electrical fields (potential gradients), shifts in gas composition gradients and alternation between exo-, thermoneutral and endothermic conditions for which cell layers and microstructures as well as stack configuration need to be optimized in order to ensure long-term stabilities and robustness. Furthermore, high system efficiency require high $(>80 \%)$ reactant conversion rates. With this objective in mind, this study aims to identify critical degradation phenomena for reversible operation and improving cell performances and stack configuration. 


\section{Experimental}

Cell structures and modifications

Different cell microstructures have been produced by Elcogen and are compared with a pre-defined reference structure. The reference structure (so-called 400-B-SM) was an anode supported cell, consisting of $\sim 400 \mu \mathrm{m} \mathrm{Ni} / 3 \mathrm{YSZ}$ support layer with $\sim 12 \mu \mathrm{m} \mathrm{Ni} / 8 \mathrm{YSZ}$ active layer, a $\sim 7 \mu \mathrm{m}$ thick LSC oxygen electrode, a $\sim 2 \mu \mathrm{m} 8 \mathrm{YSZ}$ electrolyte and a CGO barrier layer of similar thickness.

The modifications targeted the active fuel electrode, the fuel electrode support, the barrier layer and the oxygen electrode. Specifically, porosity, layer thicknesses and Ni/YSZ ratio were refined for the active and support fuel electrode structures whereas different thicknesses were produced for the oxygen electrode. The modification of the barrier layers aimed for the adjustment of the layer density, thickness and its manufacturing process. Additionally, contact layers on oxygen and fuel electrode were added or modified. A summary of the cell modifications is given in Table I.

Table I. Cell specifications (modifications compared to reference in bold)

\begin{tabular}{|c|c|c|c|c|c|c|}
\hline Cell & $\begin{array}{l}\text { Fuel } \\
\text { contact }\end{array}$ & $\begin{array}{l}\text { Fuel } \\
\text { support }\end{array}$ & $\begin{array}{l}\text { Fuel } \\
\text { active }\end{array}$ & Barrier & $\begin{array}{l}\text { Air } \\
\text { active }\end{array}$ & $\begin{array}{l}\text { Air } \\
\text { contact }\end{array}$ \\
\hline RND12 & Std & Std & Std & Std & thick & N/A \\
\hline RND21 & Std & Std & Std & Std & thick & LSC \\
\hline RND24 & smoother & Std & Std & Std & thin & N/A \\
\hline $300 \mathrm{C}$ & Std & $300 \mu \mathrm{m} /$ denser & Std & Std & thin & N/A \\
\hline ALD & Std & Std & Std & nanoALD & thin & N/A \\
\hline RND10 & Std & Std & Std & denser & thin & N/A \\
\hline RND33 & Std & Std & denser /moreNi & Std & thin & N/A \\
\hline RND36 & Std & Std & thicker & Std & thin & N/A \\
\hline RND38 & Std & Std & 2x thickness & Std & thin & N/A \\
\hline RND35 & Std & Std & thinner & Std & thin & N/A \\
\hline
\end{tabular}

$\underline{\text { Start-up and performance characterization }}$

The testing procedure started by heating the single cells $\geq 830^{\circ} \mathrm{C}$ for sealing and reduction. The $\mathrm{NiO}$ of the support and fuel electrode was reduced for $2 \mathrm{~h}$ in a 5:95 $\mathrm{H}_{2}: \mathrm{N}_{2}$ gas mixture at $20 \mathrm{l} \mathrm{h}^{-1}$ and completed for $1 \mathrm{~h}$ in pure $\mathrm{H}_{2}$ at $20 \mathrm{l} \mathrm{h}^{-1}$ at the same temperature. After reduction, the cells were initially characterized by $\mathrm{iV}$-curves and electrochemical impedance spectroscopy (EIS) at open-circuit voltage (OCV) and different $\mathrm{H}_{2} \mathrm{O} / \mathrm{H}_{2}$ ratios (i.e. 4/96, 20/80 and 50/50) to the fuel electrode and oxygen or compressed air to the oxygen electrode. The characterizations were performed at three different temperatures (i.e. $750^{\circ} \mathrm{C}, 700^{\circ} \mathrm{C}, 650^{\circ} \mathrm{C}$ ).

\section{Electrochemical Impedance Spectroscopy (EIS)}

A Solartron 1252A frequency analyzer was used to record EIS spectra for performance comparison and impedance monitoring over time. The spectra were recorded in a frequency range from $96.5 \mathrm{kHz}$ to $0.1 \mathrm{~Hz}$ and 12 points per decade. An in-house developed, Python- 
based software ('Ravdav') was used to analyse and visualize measured EIS spectra (5). The software implemented distribution of relaxation times (DRT) calculations were used for qualitative interpretation of characteristic frequency ranges for different processes (6) whereas a complex-non-linear-square (CNLS) fitting approach was applied for quantification of the impedance of the individual physical/electrochemical processes. For pristine cells, the frequency range between $11-40 \mathrm{kHz}$ can be assigned to the ionic transport in the YSZ-matrix of Ni-YSZ electrodes (7) whereas electrochemical charge-transfer processes of the fuel electrode impedance appear at $1-4 \mathrm{kHz}$ and at $0.1-0.3 \mathrm{kHz}$ for the applied type of oxygen electrode, respectively. Moreover, impedance originating from fuel diffusion and fuel conversion appear in a frequency range below $100 \mathrm{~Hz}$. $(7,8)$.

\section{Durability testing}

The cells which presented the most promising initial performances were tested for $1000-1500 \mathrm{~h}$ long-term tests and operated galvanostatically at $700^{\circ} \mathrm{C}$ and $0.6 \mathrm{~A} \mathrm{~cm}^{-2}$ supplying dry $\mathrm{H}_{2}$ in SOFC mode and at $-1.2 \mathrm{~A} \mathrm{~cm}^{-2}$ and supplying a gas composition of $90 / 10 \mathrm{H}_{2} \mathrm{O} / \mathrm{H}_{2}$ in SOEC mode. Unless stated otherwise, the reactant utilization (RU) was $85 \%$ in both operating modes and synthetic air was fed to the oxygen electrode. Degradation of the cells was evaluated either separately in each mode for periods $\geq 250 \mathrm{~h}$ or by simulating a $24 \mathrm{~h}$ energy demand and production profile ('reversible operation'). The 'reversible' testing was conducted by cycles of $16 \mathrm{~h}$ operation in SOFC mode followed by $8 \mathrm{~h}$ operation in SOEC mode.

\section{$\underline{\text { Stack optimization }}$}

Starting from the reference 25 -cell stack comprising $\sim 500 \mu \mathrm{m}$ thick cells, which was designed for a highly efficient SOEC operation (9), first an adaptation has been performed to integrate the reference $430 \mu \mathrm{m}$ thick aforementioned cells (so called Elcogen 400-B cells). Afterwards works have been performed to improve the fluidic distribution to the cells, especially on air side to cope with high flow rates as those needed for SOFC operation. Most of the work has been carried out to decrease the pressure drop on air side. Stack designed modifications have been validated first at small scale (Single Repeat Unit, SRU or 5-cell short stack) and then at 25-cell scale. For the validation of the integration of thinner cells in the stack, initial i-V curves have been recorded at $800^{\circ} \mathrm{C}$ with $90 / 10 \mathrm{H}_{2} \mathrm{O} / \mathrm{H}_{2}$

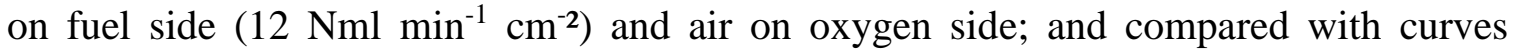
recorded on a stack comprising Elcogen 530 $\mu$ m thick cells (so-called 530-B). For the fluidic improvement of the stack design, pressure drop has been recorded on a SRU at $800^{\circ} \mathrm{C}$ as a function of the inlet air flow rate before and after stack modification. It has then been verified that the electrochemical performance, though i-V curves and ASR measurements was not affected by this modification.

\section{Results and discussion}

$\underline{\text { Cell performance and microstructure characteristics }}$

The performance of the individual cells were evaluated via EIS, measured with 50/50 $\mathrm{H}_{2} \mathrm{O} / \mathrm{H}_{2}$ fuel gas and air at $\mathrm{OCV}$ at $700^{\circ} \mathrm{C}$. Via CNLS fitting the individual contributions of the electrodes and physical processes were quantified and are listed in Table II. 
Table II. Contribution towards the total cell impedance of individual electrodes and physical processes obtained via CNLS equivalent circuit modelling fit. EIS measurements were conducted at $50 / 50 \mathrm{H}_{2} \mathrm{O} / \mathrm{H}_{2}$ and air at $\mathrm{OCV}$ at $700^{\circ} \mathrm{C}$. Based on the gas-conversion impedance the given resistances show an uncertainty of approximately $\pm 8 \%$.

\begin{tabular}{lllllll}
\hline Cell & $\begin{array}{l}\mathbf{R}_{\boldsymbol{s}} \\
\mathbf{\Omega ~ c m}^{\mathbf{2}}\end{array}$ & $\begin{array}{l}\mathbf{R}_{\boldsymbol{p}} \\
\mathbf{\Omega ~ c m}^{\mathbf{2}}\end{array}$ & $\begin{array}{l}\mathbf{R}_{\text {fuelelectrode }} \\
\mathbf{\Omega ~ c m}^{\mathbf{2}}\end{array}$ & $\begin{array}{l}\mathbf{R}_{\text {airelectrode+diff }} \\
\mathbf{\Omega}_{\mathbf{~ c m}}\end{array}$ & $\begin{array}{l}\mathbf{R}_{\text {gasconversion }} \\
\mathbf{\Omega ~ c m}^{\mathbf{2}}\end{array}$ & $\begin{array}{l}\mathbf{R}_{\text {total }} \\
\mathbf{\Omega} \mathbf{~ c m}^{\mathbf{2}}\end{array}$ \\
\hline RND12 & 0.123 & 0.135 & 0.085 & 0.015 & 0.035 & 0.258 \\
RND21 & 0.116 & 0.130 & 0.082 & 0.012 & 0.036 & 0.246 \\
\hline RND24 & 0.107 & 0.130 & 0.069 & 0.020 & 0.041 & 0.237 \\
300C & 0.099 & 0.130 & 0.054 & 0.032 & 0.044 & 0.229 \\
\hline ALD & 0.061 & 0.128 & 0.069 & 0.024 & 0.035 & 0.189 \\
RND10 & 0.145 & 0.132 & 0.077 & 0.021 & 0.034 & 0.277 \\
\hline RND33 & 0.112 & 0.215 & 0.115 & 0.061 & 0.039 & 0.327 \\
RND36 & 0.077 & 0.131 & 0.081 & 0.010 & 0.040 & 0.208 \\
RND38 & 0.089 & 0.154 & 0.093 & 0.023 & 0.038 & 0.243 \\
RND35 & 0.104 & 0.159 & 0.097 & 0.028 & 0.034 & 0.263 \\
\hline 400-B-SM & 0.109 & 0.132 & 0.067 & 0.028 & 0.037 & 0.241 \\
(reference) & & & & & & \\
\hline
\end{tabular}

The similarity of the gas conversion impedance $\left(0.038 \pm 0.003 \Omega \mathrm{cm}^{2}\right.$ which equals to $\pm 8 \%$ ) confirms similar contacted area for the different cells and thus justifies direct performance comparison without cell contact area correction. In relation to the reference structure (400-B-SM), the two barrier layer modified cells, i.e. ALD and RND10, showed the lowest and highest ohmic resistance contributions, respectively. This correlation was evidently also reflected in the thickness of the individual barrier layers with ALD < 400B-SM $<$ RND10 presented in Figure 1.
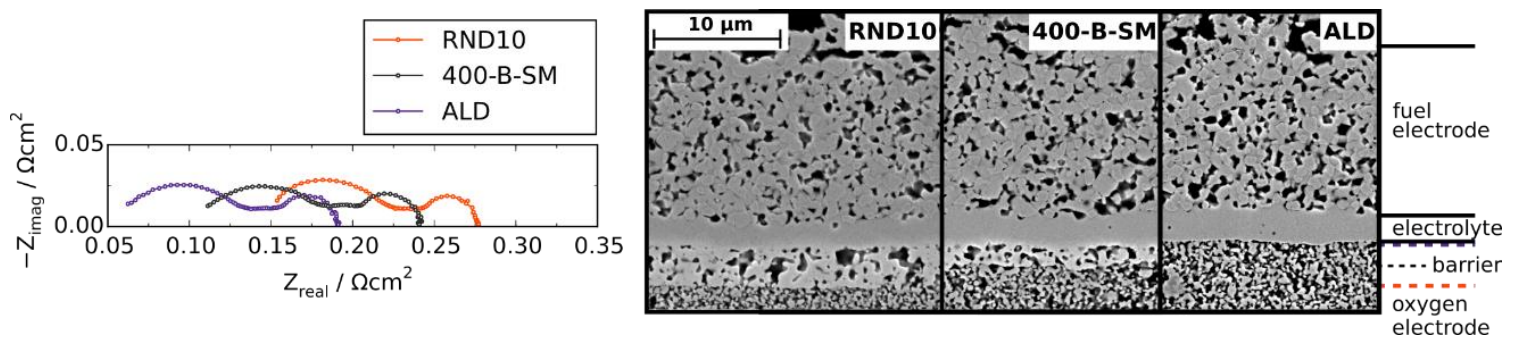

Figure 1. Comparison of electrochemical performance and microstructure features of three barrier layer modified cells. In the ALD image the barrier layer is nearly not visible due to its thickness in the order of nm. EIS were measured at $700^{\circ} \mathrm{C}$ at a fuel gas composition with $50 / 50 \mathrm{H}_{2} / \mathrm{H}_{2} \mathrm{O}$ and air at OCV. The presented Nyquist plots are corrected for inductance.

Furthermore, a clear effect in performance was observed for cell produced with ca. 2 vol\% lower porosity and higher Ni/YSZ ratio (RND33). This modification caused a fuel electrode charge-transfer impedance increase of $+0.05 \Omega \mathrm{cm}^{2}$ (vs. reference) and an increase of the diffusion/oxygen electrode resistance contribution (c.f. Table II). On the other hand, the modification of the active fuel layer thicknesses from approx. 7-20 $\mu \mathrm{m}$ did not reveal conclusive results when comparing fuel electrode charge-transfer impedance (400-B-SM 
$<$ RND36 < RND38 < RND35) and layer thicknesses (RND35 < 400-B-SM < RND36 < RND38).

In case of oxygen layer thickness modified cells, marginally better results were obtained for thicker oxygen electrodes compared to the reference. Moreover, porosity modifications of the support layer towards more homogenous and finer distributed pores lead to a slight additional improvement of fuel electrode performance, whereas contactlayer modification did not appear critical at all.

\section{Durability testing}

Initial performance evaluation guided the selection of samples for the durability tests. The tests were performed on two reference cells (400-B-SM), two cells with thicker oxygen electrode (RND21) and the initially highest performing cell with a barrier layer thickness in the $\mathrm{nm}$ range (ALD). In Figure 2 cell voltage and $\mathrm{pO}_{2}$ measurements of the outlet fuel gas over time are shown.

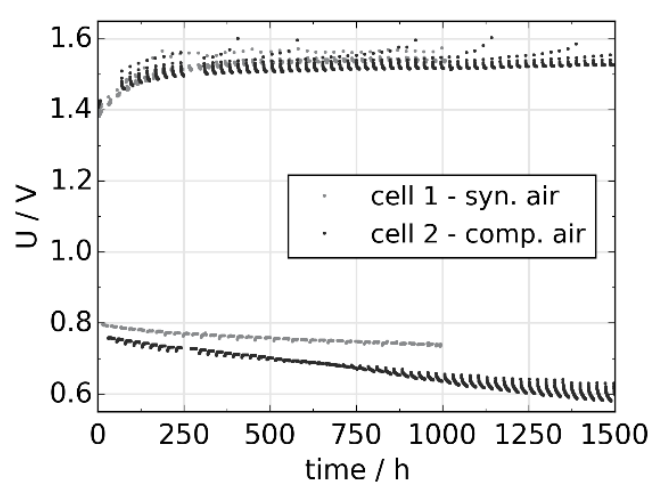

(a)

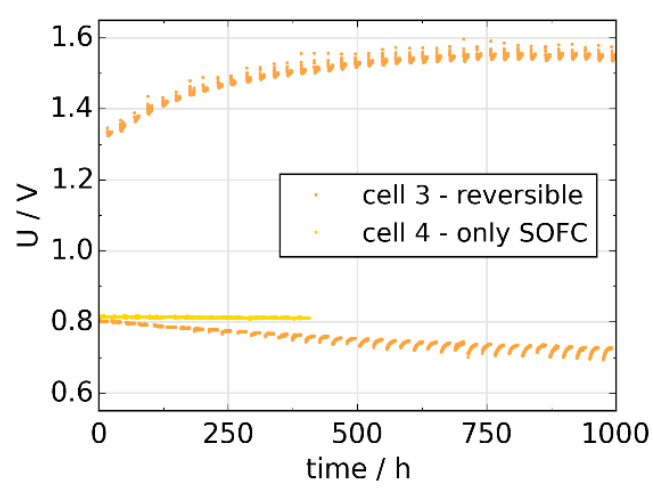

(b)

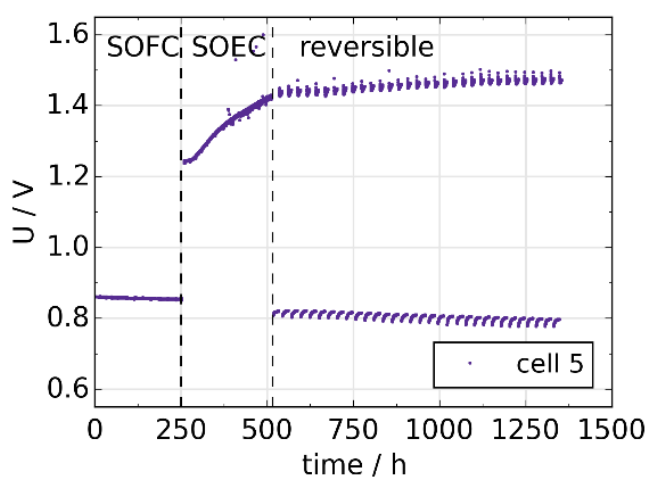

(c)

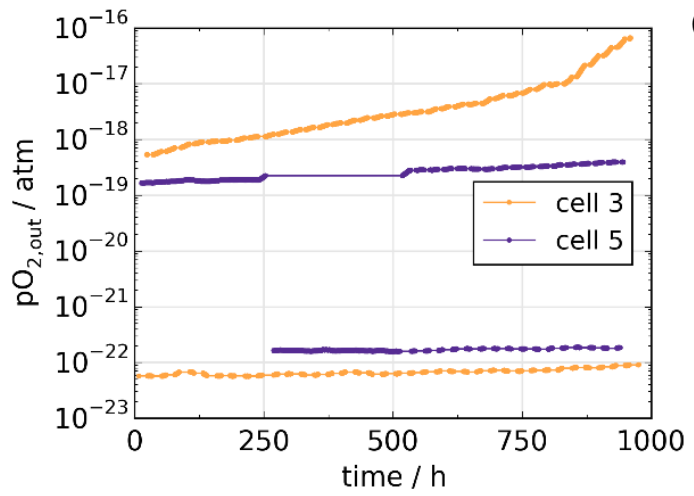

(d)

Figure 2. Comparison of long-term stabilities at $85 \% \mathrm{RU}, 700^{\circ} \mathrm{C}$ at $0.6 \mathrm{Acm}^{-2}$ in $\mathrm{SOFC}$ mode and $-1.2 \mathrm{Acm}^{-2}$ in SOEC mode: two 400-B-SM cells tested with synthetic vs. compressed air (cell 2 tested at $-0.9 \mathrm{Acm}^{-2}$ in SOEC mode) (a) two RND21 cells tested in constant vs. reversible operation (b) ALD cell tested for $250 \mathrm{~h}$ in SOFC mode and $250 \mathrm{~h}$ in SOEC mode and thereafter under reversible operation (tested $80 \%$ RU) (c) $\mathrm{pO}_{2}$ measurement of outlet fuel gas of an ALD and RND21 cell (d).

The durability tests revealed following critical degradation aspects: Firstly, cell degradation in SOFC mode shows an obvious dependency on air quality (c.f. Figure 2(a)). 
Secondly, critical initial $(250-400 \mathrm{~h})$ degradation is observed for SOEC mode operation, both for reversible and for constant operation (see Figure 2 (a) - (c)), before a kind of stabilisation. Via impedance monitoring, it could be identified that the frequency range assigned to the charge-transfer impedance of the fuel electrode was significantly affected during reversible operation.
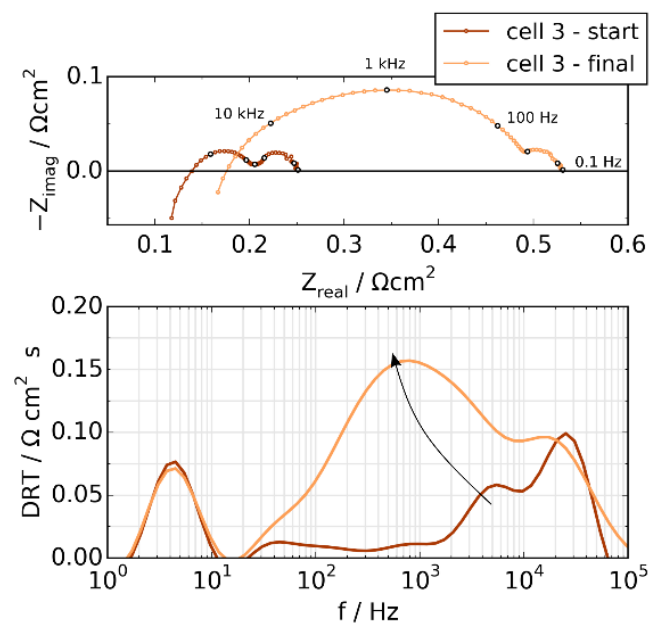

Figure 3. EIS were measured at $700^{\circ} \mathrm{C}$ at a fuel gas composition with $50 / 50 \mathrm{H}_{2} / \mathrm{H}_{2} \mathrm{O}$ and air at OCV before testing (=start) and after testing (=final). Nyquist plot (top) and DRT representation (bottom) of both measurements are presented.

The observed degradation behaviour furthermore may cause higher voltage degradation in SOFC mode during reversible operation compared to constant operation (see Figure 2 (b)). Thirdly, although high initial degradation is observed, reversible operation seems to cause cell degradation to stabilize in SOEC mode after 250-400 h. Finally, a simultaneously performed measurement of the oxygen partial pressure of the fuel outlet gas showed in some cases an increase over time (c.f. Figure 2 (d)) corresponding to an increasing $\mathrm{p}\left(\mathrm{H}_{2} \mathrm{O}\right) / \mathrm{p}\left(\mathrm{H}_{2}\right)$ ratio, indicating an unintended cross-over of gas from the oxygen electrode compartment. As reversible operation induces thermal gradients/stresses due to a shift from exo- to endotherm reaction, local mechanical degradation due to the formation of micro-cracks, and finally even macro cracks is a possibility. Yet, this observation requires further detailed investigation.

Consequently, the cell structure needs to be further specifically optimized for electrolysis operation to avoid the initially high degradation effect and ensure mechanical robustness with time. Moreover, integration of air filter systems can additionally be considered to improve long-term performances in SOFC mode.

\section{$\underline{\text { Stack optimization }}$}

Regarding the integration of $430 \mu \mathrm{m}$ thick cells, Figure 4 presents the i-V curves recorded on 3 stacks comprising this type of cell, in comparison to the performance of a stack comprising $530 \mu \mathrm{m}$ thick cells. It shows a good correlation in electrochemical performance for the 3 similar stacks comprising $430 \mu \mathrm{m}$ thick cells, and a good consistency with the stack made of thicker cells. Indeed, on the whole linear part of the i-V curve, all curves are superimposed. Only at high current densities (above $-1.2 \mathrm{~A} / \mathrm{cm}^{2}$ ), a shift in 
limiting current can appear. It can be concluded that the stack design has successfully been adapted to the change of standard thickness in cell production because the latter has no significant impact of electrochemical performance.

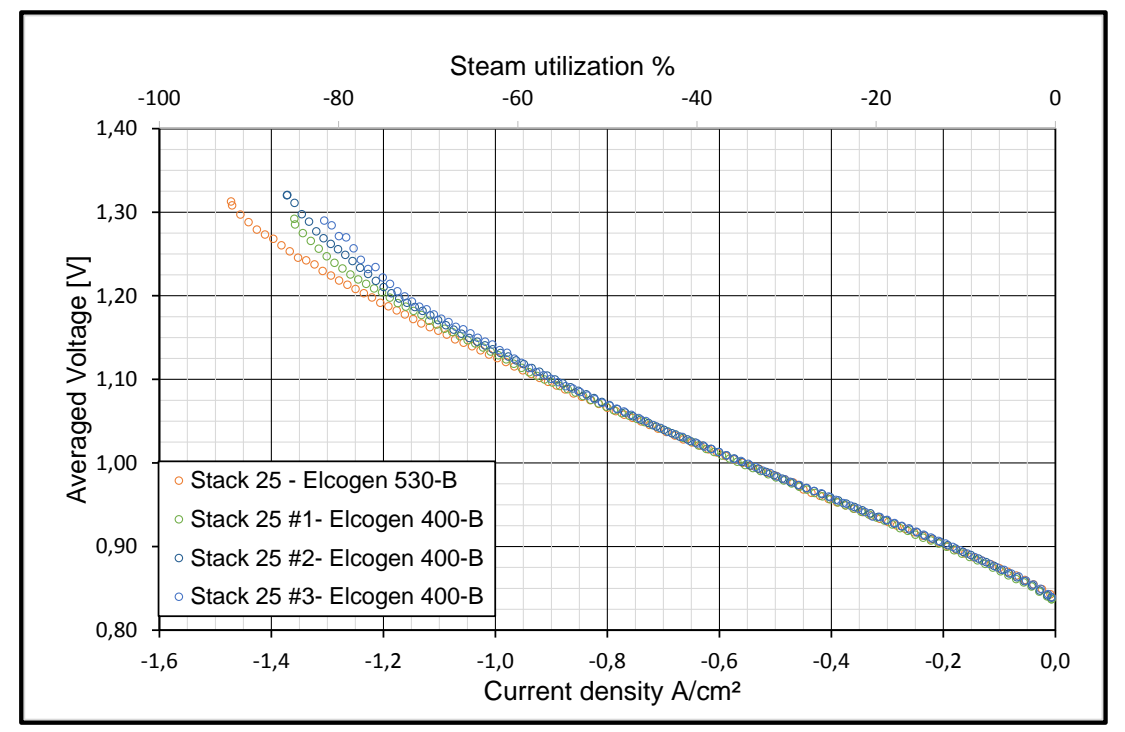

Figure 4. Comparison of SOEC mode IV curves recorded at $800^{\circ} \mathrm{C}$, with $90 / 10 \mathrm{H}_{2} \mathrm{O} / \mathrm{H}_{2}$ on fuel side $\left(12 \mathrm{Nml} \mathrm{min}^{-1} \mathrm{~cm}^{-2}\right)$ and air on oxygen side; curves with one Elcogen 530-B cells based stack and three Elcogen $400-\mathrm{B}$ cells based stack ( 25 cells) are presented; the average cell voltage is presented for all stacks.

Regarding fluidic optimization, Figure 5 illustrates the pressure drop reduction experimentally demonstrated at the SRU level. One can notice that pressure drop was reduced by a factor higher than 2 by comparison of SRU scale data. Gas path modification was then applied to 25 cell stacks. A specific curve is shown on Figure 5 that compiles results obtained for three different stacks manufactured with the modified design. One can see that the pressure drop on 25-cell stack, even if a bit higher than value recorded on a SRU, is still decreased as compared to the value recorded at SRU level before modification. The design modification to decrease the pressure drop did not modify the electrochemical performances, as shown on Figure 6 and Figure 7 in SOEC mode at SRU scale, with i-V curves and ASR measurements respectively. i-V curves and ASR evolution versus inlet flow rate obtained before and after gas path modification match very well, showing that the internal stack design modifications to decrease the pressure drop don't affect the electrochemical performances. 


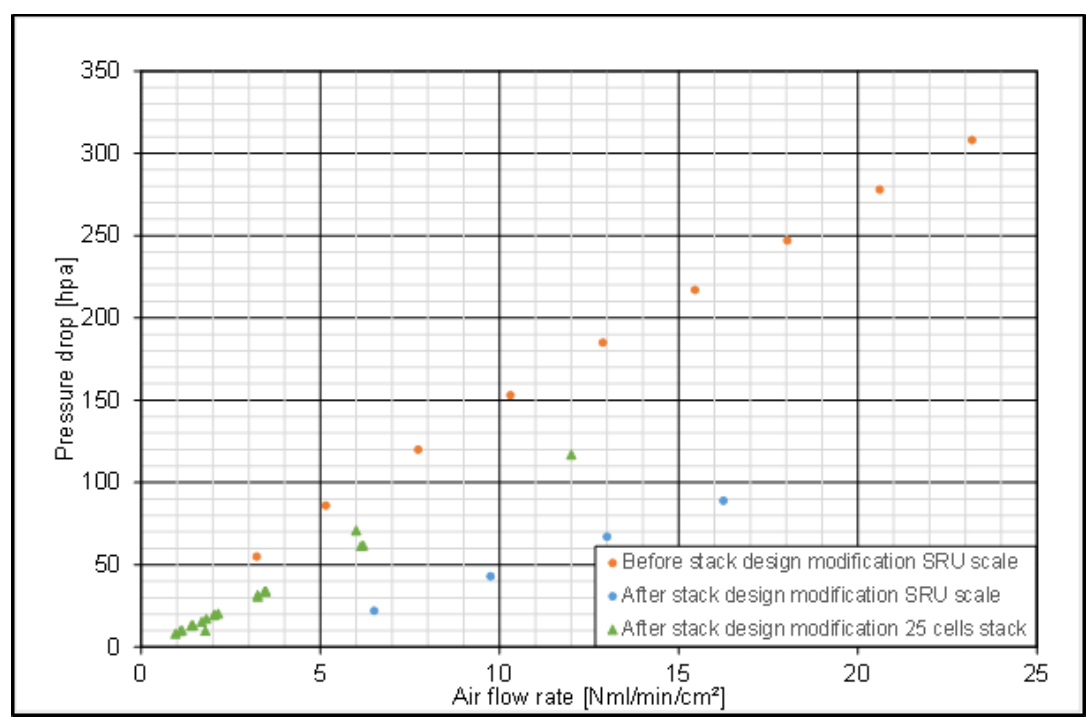

Figure 5. Pressure drop evolution at $800^{\circ} \mathrm{C}$ as a function of the inlet air flow rate before design modification as measured at SRU level; and after design modification at 25-cell stack level.

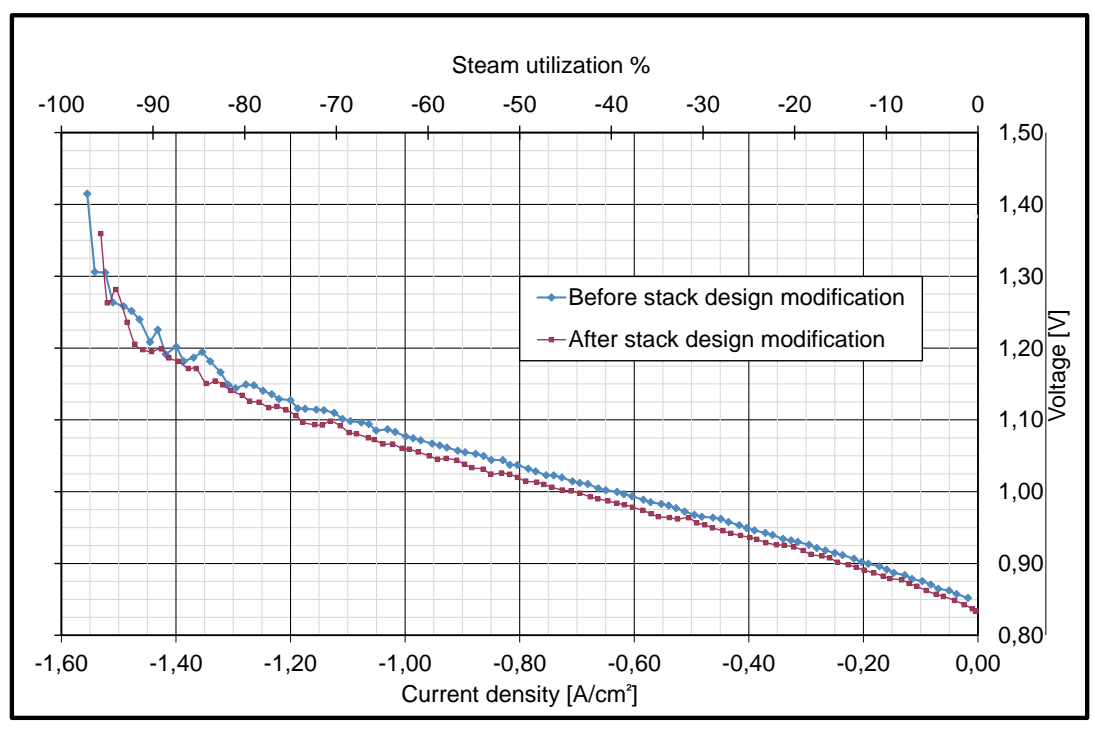

Figure 6. i-V curves in SOEC mode at $800^{\circ} \mathrm{C}$ with $90 / 10 \mathrm{H}_{2} \mathrm{O} / \mathrm{H}_{2}$ on fuel side $\left(12 \mathrm{Nml} \mathrm{\text {min } ^ { - }}\right.$ ${ }^{1} \mathrm{~cm}^{-2}$ ) and air on oxygen side, recorded at SRU level before and after design modification. 


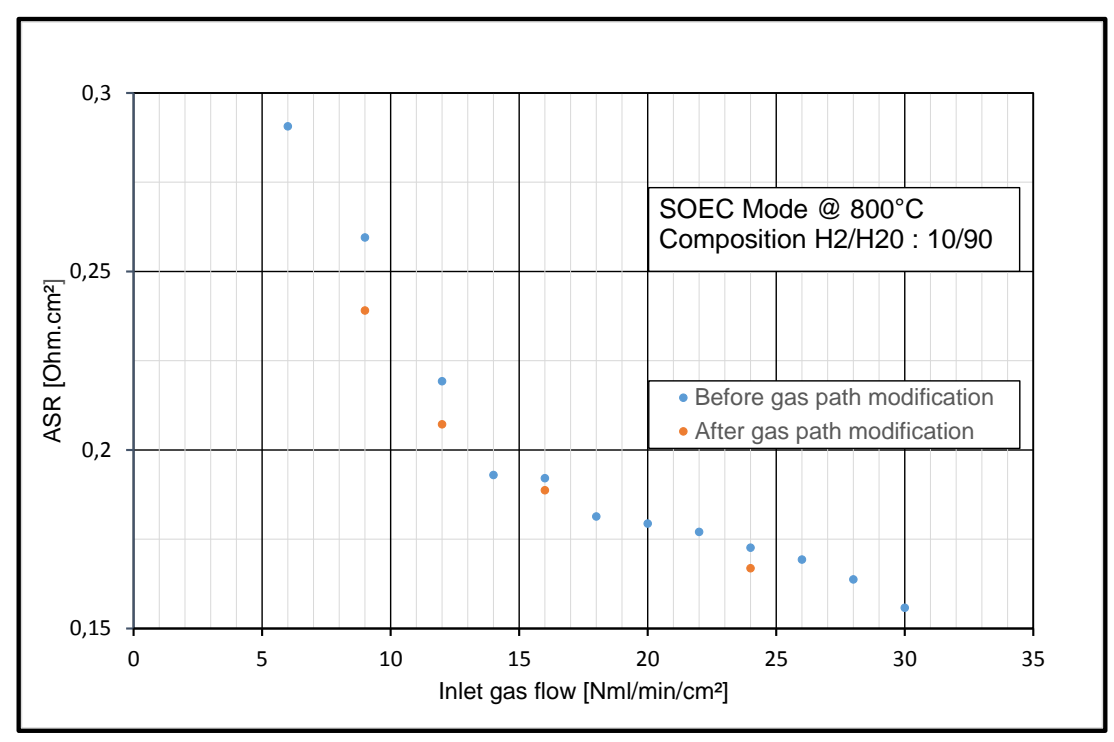

Figure 7. ASR evolutions as a function of inlet gas flow with $90 / 10 \mathrm{H}_{2} \mathrm{O} / \mathrm{H}_{2}$ on fuel side and air on oxygen side, recorded in SOEC mode at SRU level before and after design modification.

\section{Conclusion}

Electrochemical cell performance for reversible operation can be considerably enhanced by development and manufacturing cells with a nano-meter thick CGO-barrier layer. Modification of layer thicknesses led to slight improvements in oxygen electrode performance. Furthermore, long-term durability in SOEC mode seems to be primarily effected by fuel electrode degradation whereas air quality contributes significantly towards degradation in SOFC mode.

Moreover, the stack, initially designed for SOEC operation has been adapted first to integrate thinner cells, and second to decrease the pressure drop on air side to be able to feed the stack with higher flow rates as those requested in SOFC mode. Both the integration of thinner cells and the decrease of the pressure drop have been validated at the scale of a 25-cell stack, since similar electrochemical performances before and after those modifications have been obtained.

\section{Acknowledgements}

The authors would like to thank colleagues at DTU Energy for technical assistance especially H. Henriksen and E. Abdellahi. Furthermore, this work has received funding from the Fuel Cells and Hydrogen 2 Joint Undertaking under the European Union's Horizon 2020 research and innovation programme under grant agreement No. 779577 (REFLEX project). In addition SYLFEN company is acknowledged for additional support for the stack development. 


\section{References}

1. EurObserv'ER, The State of Renewable Energies in Europe,Paris, (2017) https://www.eurobserv-er.org/category/barometer-2017/.

2. X. Luo, J. Wang, M. Dooner, J. Clarke, Appl. Energy, 137, 511 (2015).

3. M. S. Khan, S.-B. Lee, R.-H. Song, J.-W. Lee, T.-H. Lim, S.-J. Park, Ceram. Int., 42, 35 (2016).

4. P. Moçoteguy, A. Brisse, Int. J. Hydrog. Energy, 38, 15887 (2013).

5. C. Graves, Ravdav Data Analysis Software, Version 0.9.8, (2012).

6. H. Schichlein, A. C. Müller, M. Voigts, A. Krügel, E. Ivers-Tiffée, J. Appl. Electrochem., 32, 875 (2002).

7. R. Barfod, M. Mogensen, T. Klemens $\emptyset$, A. Hagen, Y.-L. Liu, P. Vang Hendriksen, J. Electrochem. Soc., 154, B371 (2007).

8. T. Ramos, M. Søgaard, M. B. Mogensen, J. Electrochem. Soc., 161, F434 (2014).

9. J. Mougin, S. Di Iorio, A. Chatroux, T. Donnier-Marechal, G. Palcoux, M. Petitjean, G. Roux, ECS Trans., 78, 3065 (2017). 